\title{
Helmut Kallmann: A Life in Canadian Music
}

Helmut Kallmann, co-founder of the Canadian Music Library Association (predecessor of CAML), who died in Ottawa on 12 February 2012, in his ninetieth year, was the preeminent pioneer of Canadian music research. His A History of Music in Canada 1534-1914 (University of Toronto Press, 1960) was the first work in its field to introduce historical perspective, tracing musical life back four centuries. As a member of the editorial triumvirate of the ground-breaking Encyclopedia of Music in Canada / Encyclopédie de la musique au Canada (University of Toronto Press, 1981; Fides, 1983), as founding chief of the music division of the National Library of Canada (now Library and Archives Canada), and as chair of the Canadian Musical Heritage Society and editor of two of its twenty-five volumes, he was uniquely influential in the establishment of information and preservation mechanisms for Canadian music.

Kallmann came to Canada in the early years of World War II as an internee at a camp for "enemy aliens"; most were anti-Nazi refugees and many settled in Canada and went on to contribute significantly to the country's cultural life. Documentation indicates that camp officials commended Kallmann, then seventeen, for organizing the camp library.

During his bachelor of music studies at the University of Toronto, Kallmann was struck with the dearth of source material on Canadian music and musicians, and began to compile lists of names and dates and to collect programs and articles and especially sheet music wherever he could find them. Within months of his graduation, he wrote to Willi Apel, whose Harvard Dictionary of Music had just appeared, pointing out a few errors and offering data on the music of Canada, a topic ignored in the Dictionary. Apel's response was cordial, and Kallmann's career as a contributor to international reference works on music was launched.

He was hired as a clerk in the CBC Toronto music library, and within a few weeks of his appointment was assigned the editorship of a new edition of the Catalogue of Canadian Composers. Convinced that composition was a central feature of any musical society, he became the voluntary archivist for the Canadian League of Composers upon its formation. With other music librarians in the mid-1950s, he organized the Canadian Music Library Association as a national professional body, and also began regular correspondence with the newly-created International Association of Music Libraries (IAML). His growing reputation as the prime researcher of Canadian music and musical life led to invitations from US, English, and German publishers. He became a prolific writer.

He applied his organizing skills to the CBC library collection, and was promoted to head of the library in 1962. In 1970, when the National Library in Ottawa decided to create a music division, the first subject with that distinction, Kallmann was the logical choice to direct its formation. He remained in the position until his retirement in 1987, having seen the collection and the staff grow remarkably, and having mounted public exhibitions and 
supervised the publication of catalogues. Again it was within only a short period of his appointment in Ottawa that he was approached to work on the Encyclopedia, with the result that the 1970s and 80 s became his busiest and most productive years. In the year of his retirement, he was named a member of the Order of Canada, and the IAML journal Fontes artis musicae published a special number in his honour (vol. 34, no. 4).

By that time, he was engaged with colleagues in producing The Canadian Musical Heritage / Le Patrimoine musical canadien, a multi-volume anthology of historical Canadian music in all genres, from the eighteenth century to the mid-twentieth. By the series' completion in the late 1990s, his vision had brought reference materials and musical sources in the country into structures that were both more comprehensive and more accessible than ever before.

\section{A New Collection of Kallmann's Writings}

In 2013 Wilfrid Laurier University Press will publish Mapping Canada's Music: Selected Writings of Helmut Kallmann, jointly edited by John Beckwith and Robin Elliott. The composer John Beckwith was a close friend of Kallmann's from their student days at the University of Toronto over sixty years ago, and a collaborator in several of his projects. The musicologist Robin Elliott holds the Jean A. Chalmers Chair of Canadian Music at the University of Toronto, and is a frequent author on Canadian musical topics; he worked with Kallmann on the second edition of the Encyclopedia, and in July received the 2012 Helmut Kallmann Award from CAML. The new volume, begun (with Kallmann's knowledge and approval) in the fall of 2011, incorporates critical and research essays, reports, reflections, and personal memoirs. Items have been selected from a variety of published sources; several have not previously been published. The co-editors have benefited from access to Kallmann's extensive personal files.

Most of the writings in the new book deal with various aspects of Canadian music. Two of them-"The Making of a One-Country Encyclopedia" and the title piece, "Mapping Canada's Music"-are Kallmann's reminiscences of his professional work. The Beckwith-Elliott selection also includes items of a more personal nature, notably a long essay written during his retirement in which he recalls his life growing up in a Jewish middle-class family in 1930s Berlin. To date it has only appeared in German; the English version has not previously been published. Along with shorter accounts, one dealing with his internment years, and another with his sense of ethnic identity (a Jew, educated first in Germany, and a Canadian citizen), this article affords moving evidence of an extraordinary life. 